\title{
INTRODUCTION TO AgEING WITH EDMC
}

\author{
$\because$ Guest Editor's Introduction $\longrightarrow$ \\ DAVID MADDEN \\ PePperdine University (US)
}

David Madden is an Assistant Professor of Screen Arts at Pepperdine University. His research considers the cultural politics of electronic music from the intersections of history, technology, ageing and gender. Currently he is writing a historical book on electronic music (McGill-Queen's University Press, forthcoming) and undertaking a micro historiography of the performers of the Ondes Martenot. He is also a musician, community arts organizer and artist, whose work crosses screens, dancefloors and media. < david.madden@pepperdine.edu >

Wide-spread and often alarmist reports of the growing ageing population spreading throughout the West and beyond are contested by researchers, media makers, activists and community organizers. These groups are increasingly turning to critical approaches of age and ageing to better understand the cultural dynamics of these generational shifts. Such is the case in many parts of the world where "seniors" are the fastest growing age group who are expected to double in population in the next few decades. At the centre of this burgeoning work, scholars counter homogenous narratives of ageing populations (Mason 2018) and fear-laden narratives that are imbued with totalizing apocalyptic demographics. Typically portrayed pejoratively as the "Silver" or "Grey Tsunami", these normative accounts reaffirm what cultural historian Margaret M. Gullette calls the decline-oriented approach to age and ageing. As she writes:

Being too old, we are inveigled to believe, is a personal problem, aging.... 'Decline' is the name I use for the entire system that worsens the experience of aging-past-youth. ... Historical forces produce waves of decline. We have been enduring a tidal wave (Gullette 2011:5).

Normative associations of age and ageing tend to only link age with a numerical category and frequently associate ageing with inevitable health problems, costs and issues. These narratives of decline operate on both individual and collective consciences, shaping our responses to ageing populations and the scripts that circumscribe our behaviour.

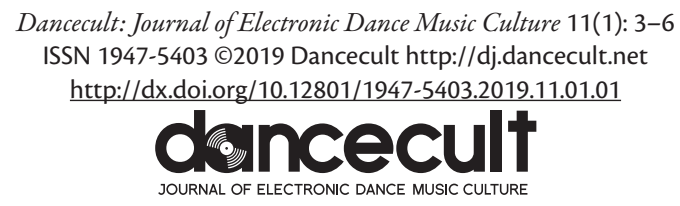


The spirit of the emerging cultural approaches to age and ageing (Katz 2005) informs the set of concerns and questions guiding this timely special edition of Dancecult: Journal of Electronic Dance Music Culture. From these cultural perspectives, ageing is understood more as an experience and as a process that is connected to social and cultural forces and contingencies. This situated view sees "age" not as a number or as a variable, but as a potential lens to examine the world. This issue brings age/ageing studies in contact with electronic dance music culture (EDMC) by highlighting the work of EDMC theorists and practitioners. It offers scholarship tied to a growing group of researchers undertaking historical cultural studies of popular music (Bennett 2013; Forman 2013; Katz 2014), gender (Jennings and Gardner 2012), memory (Grenier and Valois-Nadeau, forthcoming; Hyltén-Cavallius 2012) and ageing. The following key questions are addressed, with many more possibilities and queries calling for attention. How can stories of older DJs, producers and scene actors contribute to our understandings of age studies and EDMC? How might electronic dance music scenes and practices offer critiques of successful ageing and ageing scripts? How do relationships to musical praxis change through the passage of time?

Scholarship in this area seems long overdue, particularly in EDMC, given its intensely intimate and layered connections with time, from the highly regulated scenes that build their distinctions through attention to alternating BPMs, what Steve Goodman (2004) has referred to as "Speed Tribes", to the hyper accelerated cyclical change of musical styles (Straw 1991), and the narcotic embellishments, musical or otherwise, that play with party-goers' perceptual and temporal fields, as well as the physicality of its spaces and the bodies it draws into such temporal vortexes. Dance music scenes also have a way of both reaffirming and queering heteronormative and dominant temporalities, which presume that a life course should proceed in a linear and sequential way, from birth to death (Taylor 2010). Through different experiences of multiple life courses and through different valuations and uses of time such as "coming out", "cruising time", "ecstasy time", and "speed time", writes Jodie Taylor, queers problematize "normative progressions into adulthood and maturity", thereby "placing queers outside many categories of ageappropriate behaviour" (2010: 894).

This special edition includes Feature Articles and From the Floor contributions from a range of approaches, disciplines, settings and theoretical frameworks that consider the distinct ways to think with ageing and EDMC, broadly defined. Alice O'Grady and Anna Madill's “Being and Performing 'Older' Woman in Electronic Dance Movement Culture” focuses on a group of club-goers that usually get left out of the popular press and in EDMC scholarship. Their accounts of ageing female psytrance clubbers complicates the scene's longstanding reputation of intergenerational inclusiveness, as many of the participants in their study developed tactics to counter ageism and sexual harassment on and off the dancefloor. Through interviews and a deep engagement with EDMC's limited literature on ageing, the authors' push to the fore older women's experiences and perspectives of club culture. 
In "The Irony and the Ecstasy: The Queer Ageing of Pet Shop Boys and LCD Soundsystem in Electronic Dance Music", Larissa Wodtke discusses the aesthetics of irony and ambivalence in the work of these two pop and rock infused dance groups. Wodtke details their belated musical ascension, coming when Neil Tennant (Pet Shop Boys) and James Murphy (LCD) were both in their 30s, and its challenge to the youth-oriented foundations of popular music and the hedonism of EDM. This positionality, claims the author, places them in a queer tension as they balance and negotiate their "old age" (in pop terms) within these youthful settings.

Lastly, with "Baby Raves: Youth, Adulthood and Ageing in Contemporary British EDM Culture", Zoe Armour examines the limits of age in translocal EDM sound system and super(club) culture through interrogating formations of intergenerational relationships across a wide spectrum of party attendees. Armour then looks at the baby rave phenomenon, which she periodizes from 2004 onward, as it relates to notions of heritage, and the way these raves have tapped into a new and robust consumer market and thereby generating new festival and super(club) experiences.

The issue includes an additional Feature Article: Carlos Palombini's "A Danceable Shower of Bullets: Sound Morphologies, Concrescence and Neurosis in the Genesis of an EDM Beat."

With the assistance of From the Floor Editor Dave Payling, the FTF section brings together several pieces, including a snapshot of one of Brazil's most important hip-hop scenes and an interview with one of electronic music's most controversial figures. Michel Brasil offers "Boom Bap, Trap and Ageing in Belo Horizonte's Rap Music Scene", his account of ageing rappers and beatmakers in Brazil's sixth largest city. Tristan Kneschke interviews Genesis Breyer P-Orridge, perhaps best known as the front-person of the industrial art music group Throbbing Gristle, who's recently been in the news due to her health problems and reports of abuse that continue to complicate her artistic legacy. In "Travellers and Sound System Protest: Matthew Smith's Visual Commentary”, Dave Payling reviews Exist to Resist, Smith's photo-journey through UK underground dance music culture (the piece includes an interview with Smith). Alistair Fraser explores "Death of/in British Drum 'n' Bass Music". DJ Donna Bentley asks "Have Things Really Changed, or is it Just Me? Ageing and Dance Music Culture". And finally, Sébastien Lavoie explains "My Practice of Live Performance of Spatial Electronic Dance Music".

Let these contributions provide an opening for more EDMC studies of age and ageing. These studies might attend to the changing valuations of dance music's material culture, or to the way scenes, genres and artists' careers change in relation to the contingencies of time. Ageing offers an approach to interrogate the world, lived experiences and the pressures, promises, rhythms and vibes that surround us. 


\section{ACKNOWLEDGEMENTS}

Many thanks to the contributors for their timely works and to Dancecult and Graham St John for making this special edition possible. This research was generously funded by Ageing + Communication + Technologies (ACT), and the Social Sciences and Humanities Research Council of Canada (SSHRC). I also want to thank Pepperdine University and the Communication Division for their ongoing support as well.

\section{REFERENCES}

Bennett, Andy. 2013. Music, Style and Aging: Growing Old Disgracefully? Philadelphia, PA: Temple University Press.

Forman, Murray. 2013. "Kill the Static: Temporality and Change in the Hip-Hop Mainstream (and its 'Other')". In Redefining Mainstream Popular Music, Sara Baker, Andy Bennet and Jodie Taylor, ed., 61-74. New York: Routledge.

Goodman, Steve. 2004. "Speed Tribes: Netwar, Affective Hacking and the Audio-Social”. In Cultural Hacking, ed. Thomas Dullo and Franz Liebl, 139-55. Berlin: Springer-Verlag.

Grenier, Line and Valois-Nadeau, Fannie. Forthcoming. A Senior Moment: Cultural Mediations of Memory and Ageing. Bielefeld Germany: Transcript Verlag.

Gullette, Margaret, M. 2011. Agewise: Fighting the New Ageism in America. Chicago and London: The University of Chicago Press.

Hyltén-Cavallius, Sverker. 2012. "Memoryscapes and Mediascapes: Musical Formations of 'Pensioners' in late 20th-Century Sweden”. Popular Music 31(2): 279-95. $<$ https://doi.org/10.1017/S0261143012000050>.

Jennings, Ros and Gardner, Abigail. 2012. 'Rock on': Women, Ageing and Popular Music. Burlington, VT: Ashgate.

Katz, Stephen. 2014. "Music, Performance and Generation: The Making of Boomer Biographies". In Aging, Media, Culture, ed. C. Lee Harrington, Denise D. Bielby and Anthony R. Bardo, 93-106. Lanham, MD: Lexington Books.

- - - 2005. Cultural Aging: Life Course, Lifestyle, and Senior Worlds. Peterborough, ON: Broadview Press.

Mason, Melanie. 2018. "California's Senior Population is Growing Faster Than Any Other Age Group. How the Next Governor Responds is Crucial”. La Times, 7 October. $<$ https://www.latimes.com/projects/la-pol-ca-next-california-demographics $>$ (Accessed 16 October 2019).

Straw, Will. 2001. "Systems of Articulation, Logics of Change: Scenes and Communities in Popular Music". Cultural Studies 5(3): 368-88. < https://doi.org/10.1080/09502389100490311>.

Taylor, Jodie. 2010. "Queer Temporalities and the Significance of 'Music Scene' Participation in the Social Identities of Middle-aged Queers". Sociology 44(5): 893-907. $<$ https://doi.org/10.1177/0038038510375735>. 